\title{
Diagnostic Value of Serum Heat Shock Protein 70 in Hepatocellular Carcinoma Patients
}

\author{
Ahmed Ebrahim Ahmed Elhammar ${ }^{1}$, Amany Mohamed Ibrahim², \\ Amina Mohamed Talaat Elnaggar ${ }^{3}$, Emad Fawzi Hamed ${ }^{2}$, \\ ${ }^{1}$ Internal Medicine Department, Al-Ahrar Teaching Hospital, Zagazig, Egypt. \\ ${ }^{2}$ Internal Medicine Department, Faculty of Medicine, Zagazig University, Egypt. \\ ${ }^{3}$ Clinical Pathology Department, Faculty of Medicine, Zagazig University, Egypt.
}

Corresponding Author Ahmed Ibrahim Ahmed

Mobile:

$+201129933126$

E mail:

arwaebrahim201457@ gmail.com

Key words: Hepatocellular carcinoma, Liver cirrhosis, Heat Shock Protein 70
Background and study aim: Hepatocellular carcinoma (HCC) is the commonest essential hepatic threat among adult. Nowadays, the HCC determination without obsessive relationship is done by imaging methods. To elucidate the role of heat shock protein 70(HSP70) in the diagnosis of HCC.

Subjects and Methods: This case control study was achieved in Internal Medicine and Clinical Pathology Departments, Zagazig University, Egypt. It involved 99 participants divided into three groups; control group, cirrhotic patients and cirrhotic patients with HCC. Participants underwent complete history taking, comprehensive clinical examination, laboratory investigations including viral markers and alpha-fetoprotein. HSP 70 level was calculated via the enzyme-linked immunosorbent assay (ELISA) technique. Radiological investigations including abdominal ultrasonography and triphasic CT scan were done.
Results: There was a non-significant difference between the studied groups concerning demographic characteristics. There was a significant difference between them regarding hemoglobin, platelet count, liver and kidney function tests and coagulation profile $(\mathrm{p}<0.05)$. Also, there was a significant difference between them as regards HSP 70, and AFP with the maximum values in HCC group. HSP 70 at cutoff $\geq 120 \mathrm{ng} / \mathrm{ml}$ can diagnose $\mathrm{HCC}$ at sensitivity $85 \%$, specificity $50 \%$, and accuracy $84 \%$ $(\mathrm{p}<0.05)$. AFP at cutoff $\geq 20 \mathrm{ng} / \mathrm{ml}$ can recognize $\mathrm{HCC}$ with sensitivity $87.5 \%$, specificity $75.8 \%$ and accuracy $89 \%$. Combined HSP 70 and AFP increase the sensitivity of diagnosis at $91.5 \%$ and accuracy to $93 \%$.

Conclusion: HSP 70 as a serum biomarker can be used with AFP to increase the accuracy of HCC diagnosis.

\section{INTRODUCTION}

Hepatocellular carcinoma is the fifth most common tumor among males and the seventh most malignant growth among females. Hepatitis B and hepatitis $\mathrm{C}$ diseases are the most basic hazard factors for HCC [1].

In 2001, non-invasive imaging technique was accepted to diagnose $\mathrm{HCC}$ in presence of a cirrhotic liver [2].

As early small lesions are asymptomatic and additionally, there is shortage of satisfactory diagnostic and screening strategies, most patients (>80\%) present with an advanced phase. At the present, serum alpha-fetoprotein (AFP) level and ultrasonography are the most utilized screening procedures in cirrhotic patients [3].

There are about $30 \%$ of those patients with normal serum AFP levels are hardly diagnosed before any clinical manifestations appear, so, AFP alone is restricted and poorly reliable for early diagnosis of HCC [4].

This highlights the necessity for emerging prognostic and accurate diagnostic biomarkers for HCC. Tumor markers detection in human serum is the most reliable method because it is suitable, noninvasive, inexpensive and clear-cut. The seventy kilodalton warm stun proteins (Hsp70s) are a bunch of ubiquitously communicated warm stun proteins exist in for all intents and

Elhammar et al., Afro-Egypt J Infect Endem Dis 2019; 9(3):216-223

https://aeji.journals.ekb.eg/

http://mis.zu.edu.eg/ajied/home.aspx 
purposes all living beings. HSP 70 family of proteins are thought to be effective buffering framework for cellular strain, either from outward (physiological, viral and natural) or inborn (replicative or oncogenic) boosts. As such, this family serves a genuine survival work in the cell. Not incredibly, cancer cells depend on this buffering framework for survival [5-8].

Serum HSP70 levels serially increased in patients with chronic hepatitis, liver cirrhosis, and liver carcinomas, revealing a possible prognostic value [6], and are also typically positive in Intrahepatic Cholangiocarcinoma ( $\mathrm{IH}-\mathrm{ChCa}$ ) and metastatic tumors [7].

HSP70 expression was higher in the four sorts of HCC cell lines compared to the normal cells, in agreement within HCC tissues specimens and other types of malignant tumors, including lung cancer, breast cancer and colorectal carcinoma [8]. So our study aimed to illuminate the role of HSP 70 in the diagnosis of HCC.

\section{SUBJECTS AND METHODS}

\section{Study design and site:}

A case control study was done in Internal Medicine and Clinical pathology Departments, Faculty of Medicine, Zagazig University, during the period from January 2017 to August 2018.

\section{Study population:}

A total number of 99 contributors were involved and categorized into three main groups: Group 1 apparently healthy individuals, Group 2 liver cirrhosis and Group 3 HCC.

\section{Inclusion criteria for patients:}

\section{1- Patients with Post-hepatitis C Cirrhosis [9].}

2- Patients with newly diagnosed HCC (Stage A and B) following Barcelona clinic liver cancer staging [10].

\section{Exclusion criteria for patients:}

History of other malignancies, autoimmune liver diseases, chronic HBV, NAFLD and primary biliary cirrhosis. History of acute and chronic inflammatory diseases and sepsis. Also, patients with COPD, bronchial asthma, glomerulonephritis, diabetes mellitus, stroke and seizure-related events were excluded.

\section{All subjects of the study were subjected to the following:}

Full history taking, detailed clinical examination and routine laboratory investigations (complete blood picture, liver function tests, renal function tests,HbA1C,random blood glucose, Coagulation profile (PT, PTT, and INR), viral marker: (HBs Antigen, $\mathrm{HBc}$ antibody and $\mathrm{HCV}$ Antibody). Also the other investigations required for accomplishing the exclusion criteria. Pelvi abdominal ultrasonography was done for all participants but abdominal Triphasic CT was done for all patients.

\section{Measurement of AFP:}

Blood sample $(3 \mathrm{~cm})$ was taken from every subject and then centrifuged, and serum was used for quantifying AFP by cobas 8000 (e602).

\section{Measurement of Heat Shock Protein 70 by ELISA:}

Four $\mathrm{ml}$ of peripheral venous blood samples were taken by venipuncture from all patients and healthy controls. One $\mathrm{ml}$ blood in container enclosing EDTA for CBC then the samples were left to clot serum was separated. It was stored at $80^{\circ} \mathrm{C}$ until measuring HSP 70 level.

\section{Statistical Analysis}

All information were collected, arranged and factually analyzed utilizing SPSS 20.0 for Windows (SPSS Inc., Chicago, IL, USA). Quantitative information were expressed as the cruel \pm SD\& middle (extend), and subjective information were communicated as outright frequencies (number) $\&$ relative frequencies (\%). Nonstop information were checked for ordinariness by utilizing the Shapiro Walk test. Mann-Whitney U was utilized to compare two bunches of non-normally conveyed information. To compare implies of more than two bunches, one way ANOVA was utilized (when information is ordinarily disseminated). Kruskal Wallis test was utilized to compare medians of more than two bunches (when data isn't regularly dispersed). ROC bend was used to identify the most excellent cutoff value of HSP 70 and AFP within the conclusion of HCC. A p-value $<0.05$ is considered statistically significant, while $\mathrm{p} \leq 0.001$ is considered statistically highly significant. 


\section{RESULTS}

There's a measurably non-significant distinction between the considered patients as respect age, sex and BMI (Table 1).

There was a statistically significant difference between the studied groups as concern hemoglobin level, PT, PTT, INR; platelets count total and direct bilirubin, ALT, AST, serum albumin and creatinine. However, there was a statistically non-significant difference between them regarding TLC (Table 2).

There was non- significant difference in ChildPugh score classification between HCC and the liver cirrhotic patient groups (Table 3).

Our study displayed that there is a highly statistically significant difference between the studied groups as regard Heat shock protein 70 and AFP. The group of patients with HCC had the maximum levels of both markers (Table 4).

Performance of HSP 70 and AFP in the diagnosis of HCC among the studied patients at a cutoff of HSP 70 more than or equal $120 \mathrm{ng} / \mathrm{ml}$, it can diagnose HCC with sensitivity $85 \%$, specificity $50 \%$, PPV $80 \%$, NPV $75 \%$ and accuracy $84 \%$.At a cutoff of $\geq 20 \mathrm{ng} / \mathrm{ml}$, AFP can diagnose HCC at a sensitivity of $87.5 \%$, specificity $75.8 \%$, PPV $66.7 \%$, NPV 89\% and accuracy $89 \%$. Using combined cutoff of both markers, the sensitivity increases up to $91.5 \%$ with specificity $65.8 \%$, PPV 76.7\%, NPV 91 and accuracy 93\% (Fig 1 and Table 5).

Table (1): Comparison between the studied groups regarding demographic and anthropometric data

\begin{tabular}{|c|c|c|c|c|c|c|c|c|}
\hline Variable & \multicolumn{2}{|c|}{$\begin{array}{c}\text { Group1 } \\
\text { Control(33) } \\
\end{array}$} & \multicolumn{2}{|c|}{$\begin{array}{c}\text { Group2 } \\
\text { Cirrhotics (33) } \\
\end{array}$} & \multicolumn{2}{|c|}{$\begin{array}{c}\text { Group3 } \\
\text { HCC (33) }\end{array}$} & $\begin{array}{c}\text { F } \\
\text { test }\end{array}$ & $\mathbf{p}$ \\
\hline $\begin{array}{l}\text { Age(years) } \\
\text { mean } \pm \text { SD } \\
\text { Range }\end{array}$ & \multicolumn{2}{|c|}{$\begin{array}{c}56.7 \pm 5.1 \\
(45-64)\end{array}$} & \multicolumn{2}{|c|}{$\begin{array}{c}57.6 \pm 5.2 \\
(49-67)\end{array}$} & \multicolumn{2}{|c|}{$\begin{array}{c}59.9 \pm 4.7 \\
(52-68)\end{array}$} & 1.2 & 0.08 \\
\hline $\begin{array}{c}\mathbf{B M I}\left(\mathbf{k g} / \mathbf{m}^{2}\right) \\
\text { mean } \pm \mathrm{SD} \\
\text { Range } \\
\end{array}$ & \multicolumn{2}{|c|}{$\begin{array}{l}23.9 \pm 2.3 \\
(21.5-28) \\
\end{array}$} & \multicolumn{2}{|c|}{$\begin{array}{c}23.9 \pm 2.7 \\
(19.5-29.5) \\
\end{array}$} & \multicolumn{2}{|c|}{$\begin{array}{c}21.4 \pm 2.2 \\
(17.5-26.3) \\
\end{array}$} & 1.5 & 0.07 \\
\hline Variable & \multicolumn{2}{|c|}{ Group1 } & \multicolumn{2}{|c|}{ Group2 } & \multicolumn{2}{|c|}{ Group3 } & $\chi^{2}$ & $\mathbf{p}$ \\
\hline $\begin{array}{l}\text { Sex: } \\
\text { Male (58) } \\
\text { Female (41) }\end{array}$ & $\begin{array}{l}15 \\
18\end{array}$ & $\begin{array}{l}45.5 \\
54.5\end{array}$ & $\begin{array}{l}22 \\
11\end{array}$ & $\begin{array}{l}66.7 \\
33.3\end{array}$ & $\begin{array}{l}21 \\
12\end{array}$ & $\begin{array}{l}63.6 \\
36.4\end{array}$ & 3.5 & 0.16 \\
\hline
\end{tabular}


Table (2): Comparing laboratory investigations between the studied groups

\begin{tabular}{|c|c|c|c|c|c|}
\hline Variable & $\begin{array}{c}\text { Group 1 } \\
\text { Control (33) } \\
\text { mean } \pm \text { SD } \\
\text { Range }\end{array}$ & $\begin{array}{c}\text { Group 2(33) } \\
\text { Cirrhotic patients } \\
\text { mean } \pm \text { SD } \\
\text { Range }\end{array}$ & $\begin{array}{c}\text { Group 3 } \\
\text { HCC (33) } \\
\text { mean } \pm \text { SD } \\
\text { Range }\end{array}$ & $\mathbf{F}$ & $\mathbf{p}$ \\
\hline $\mathbf{H b}(\mathrm{g} / \mathrm{dl})$ & $\begin{array}{c}12.6 \pm 1.3 \\
(10.9-14.7)\end{array}$ & $\begin{array}{l}11.2 \pm 1.1 \\
(9.2-14)\end{array}$ & $\begin{array}{c}10.4 \pm 1.3 \\
(8.1-14.4)\end{array}$ & $\mathrm{F}=33$ & 0.001 \\
\hline $\operatorname{TLC}\left(\times 10^{3} / \mathrm{mm}^{3}\right)$ & $\begin{array}{c}7.1 \pm 0.9 \\
(5.6-9.1)\end{array}$ & $\begin{array}{c}7.2 \pm 1.8 \\
(4.2-10.5)\end{array}$ & $\begin{array}{l}7.4 \pm 8.7 \\
(1.9-54)\end{array}$ & KW 3.7 & 0.8 \\
\hline Platelets $\left(\times 10^{3} / \mathrm{mm}^{3}\right)$ & $\begin{array}{c}287.70 \pm 63.14 \\
(179-423) \\
\end{array}$ & $\begin{array}{c}105.09 \pm 41.24 \\
(63-254)\end{array}$ & $\begin{array}{c}110.21 \pm 48.48 \\
(58-225)\end{array}$ & $\mathrm{F}=133.2$ & $<0.001$ \\
\hline PT $(\mathrm{Sec})$ & $\begin{array}{l}10.38 \pm 0.45 \\
(10.0-11.3)\end{array}$ & $\begin{array}{l}14.29 \pm 1.60 \\
(11.7-18.0)\end{array}$ & $\begin{array}{l}14.72 \pm 1.66 \\
(11.7-18.0)\end{array}$ & 102.8 & $<0.001$ \\
\hline PTT (Sec) & $\begin{array}{l}29.63 \pm 0.91 \\
(28.8-32.3)\end{array}$ & $\begin{array}{l}38.55 \pm 4.72 \\
(31.0-45.0)\end{array}$ & $\begin{array}{l}39.97 \pm 3.98 \\
(31.0-45.0)\end{array}$ & 79.7 & $<0.001$ \\
\hline INR & $\begin{array}{c}1.04 \pm 0.13 \\
(0.9-1.2) \\
\end{array}$ & $\begin{array}{c}1.51 \pm 0.40 \\
(1.0-2.7) \\
\end{array}$ & $\begin{array}{c}1.68 \pm 0.51 \\
(1.0-2.8) \\
\end{array}$ & 24.7 & $<0.001$ \\
\hline $\begin{array}{l}\text { Total bilirubin } \\
(\mathrm{Mg} / \mathrm{dl})\end{array}$ & $\begin{array}{c}0.92 \pm 0.15 \\
(0.6-1.2)\end{array}$ & $\begin{array}{c}2.20 \pm 0.76 \\
(0.8-3.6)\end{array}$ & $\begin{array}{c}2.38 \pm 0.76 \\
(1.0-4.0) \\
\end{array}$ & 53.1 & $<0.001$ \\
\hline $\begin{array}{c}\text { Direct bilirubin } \\
(\mathrm{Mg} / \mathrm{dl})\end{array}$ & $\begin{array}{c}0.30 \pm 0.11 \\
(0.1-0.5) \\
\end{array}$ & $\begin{array}{c}0.87 \pm 0.38 \\
(0.2-1.7) \\
\end{array}$ & $\begin{array}{c}0.99 \pm 0.43 \\
(0.3-1.8) \\
\end{array}$ & 40.3 & $<0.001$ \\
\hline ALT (IU/L) & $\begin{array}{c}24.3 \pm 4.5 \\
(15-31)\end{array}$ & $\begin{array}{c}25.3 \pm 7.8 \\
(15-50)\end{array}$ & $\begin{array}{c}43.9 \pm 12.3 \\
(35-80)\end{array}$ & 42 & 0.001 \\
\hline AST (IU/L) & $\begin{array}{c}23.8 \pm 4.9 \\
(13-31) \\
\end{array}$ & $\begin{array}{c}28.3 \pm 6.2 \\
(13-42) \\
\end{array}$ & $\begin{array}{c}40.9 \pm 18.8 \\
(30-92) \\
\end{array}$ & 67.2 & 0.001 \\
\hline Albumin (g/dl) & $\begin{array}{l}4.3 \pm 0.3 \\
(3.8-5) \\
\end{array}$ & $\begin{array}{c}3.1 \pm 0.48 \\
(2.1-4) \\
\end{array}$ & $\begin{array}{c}2.8 \pm 1.4 \\
(1.8-3.4) \\
\end{array}$ & 26 & 0.001 \\
\hline Creatinine $(\mathrm{Mg} / \mathrm{dl})$ & $\begin{array}{l}0.81 \pm 0.2 \\
(0.4-1.2)\end{array}$ & $\begin{array}{c}1.08 \pm 0.13 \\
(0.9-1.5)\end{array}$ & $\begin{array}{c}1.2 \pm 0.1 \\
(0.9-1.6)\end{array}$ & 35 & 0.001 \\
\hline
\end{tabular}

Table (3):Comparing Child Pugh classification between HCC and the liver cirrhosis patients groups

\begin{tabular}{|c|c|c|c|c|c|c|}
\hline $\begin{array}{l}\text { Child Pugh } \\
\text { classification }\end{array}$ & \multicolumn{2}{|c|}{$\begin{array}{c}\text { Group2 } \\
\text { Cirrhotic patients }\end{array}$} & & $\chi^{2}$ & p-value \\
\hline $\mathbf{A}$ & 14 & 42.4 & 12 & 36.4 & \multirow{2}{*}{0.254} & \multirow{2}{*}{0.614} \\
\hline B & 19 & 57.6 & 21 & 63.6 & & \\
\hline
\end{tabular}


Table (4): Comparing Heat shock protein 70 and AFP between the studied groups

\begin{tabular}{|l|c|c|c|c|c|}
\multicolumn{1}{|c|}{ Variable } & $\begin{array}{c}\text { Group 1 } \\
\text { Control (33) }\end{array}$ & $\begin{array}{c}\text { Group 2 (33) } \\
\text { Cirrhotic patients }\end{array}$ & $\begin{array}{c}\text { Group 3 } \\
\text { HCC (33) }\end{array}$ & F-test & p \\
\hline $\begin{array}{l}\text { Heat shock protein 70 }(\mathrm{ng} / \mathrm{ml}) \\
\text { mean } \pm \text { SD } \\
\text { Range }\end{array}$ & $\begin{array}{c}91.5 \pm 13.9 \\
(62-121)\end{array}$ & $\begin{array}{c}116.2 \pm 18.3 \\
(87-156)\end{array}$ & $\begin{array}{c}143.9 \pm 33.1 \\
(97-217)\end{array}$ & 41.8 & $\mathbf{0 . 0 0 1}$ \\
\hline $\begin{array}{l}\text { AFP (ng/ml) } \\
\text { mean } \pm \text { SD } \\
\text { Range }\end{array}$ & $\begin{array}{c}5.9 \pm 0.9 \\
(3-9)\end{array}$ & $\begin{array}{c}11.7 \pm 6.6 \\
(4-25)\end{array}$ & $\begin{array}{c}465.1 \pm 280 \\
(49-1120)\end{array}$ & 8.7 & $\mathbf{0 . 0 0 1}$ \\
\hline
\end{tabular}

Table (5); Performance of HSP 70, AFP and their combination in the detection of HCC

\begin{tabular}{|l|c|c|c|c|c|c|c|c|}
\hline Variable & Cutoff & AUC & Sensitivity & Specificity & PVP & PVN & Accuracy & P \\
\hline HSP 70 & 120 & 0.84 & 85 & 50 & 80 & 75 & 84 & $<0.001$ \\
\hline AFP & 20. & 0.89 & 87.5 & 75.8 & 66.7 & 89 & 89.0 & $<0.001$ \\
\hline
\end{tabular}

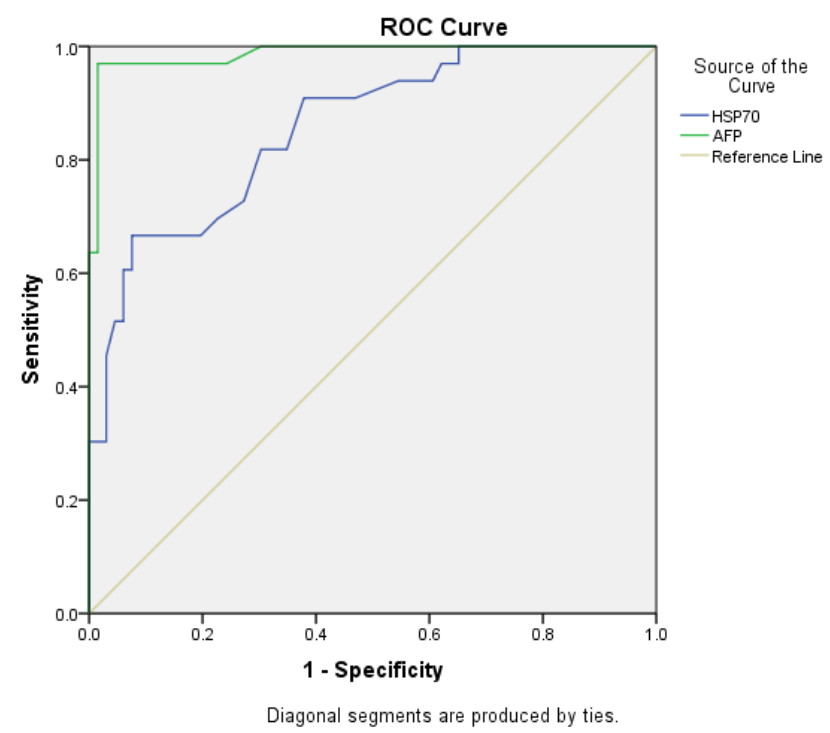

Fig. (1) : ROC curve showing the performance of HSP 70 and alpha fetoprotein detection of HCC.

\section{DISCUSSION}

$\mathrm{HCC}$ is one of the commonest malignancies [11]. It is estimated to be in charge for almost 746,000 deaths in $2012(9.1 \%$ of the total patients with cancer) [12].

HCC diagnosis at early stage has a far better prognosis owing to availability of potentially curative therapies. Hence, screening and diagnosis of HCC in patients with liver cirrhosis is extremely important.AFP still lacks adequate sensitivity and specificity for active HCC screening [13].
Frequent other biomarkers such as des-gamma carboxy-prothrombin, glypican-3, human hepatocyte growth factor, and insulin-like growth factor-1 are promising, but none of these markers has been licensed for clinical use. Another potential biomarker for HCC is Heat Shock Protein 70 (HSP70). HSPs have been conveyed to be overexpressed in a wide range of human tumors. HSPs expression was related to tumor cell growth, differentiation, resistance to apoptosis, and poor prognosis [14]. 
So, the aim of our study was to illuminate the role of heat shock protein 70 in the diagnosis of Hepatocellular carcinoma.

In our study, the mean age of patients with HCC was $59.9 \pm 4.7$ years. Larger percentage of them was male. Due to appropriate randomization, there was a statistically non-significant difference between the three groups concerning age or gender.

There is a move to younger age in the developing countries which may be accredited to the rise of both hepatitis $\mathrm{B}$ and or $\mathrm{C}$ infections at a younger generation. Old age is an independent risk factor for $\mathrm{HCC}$, especially in areas where $\mathrm{HCV}$ infection is endemic [15]. El Zayadi and his colleagues[16] stated that the most predominant age group was (40-59 years).

Zakhary et al. [15] found that males constituted $70.8 \%$ of all patients in the HCC group, with $83.3 \%$ of patients over 50 years. HCC was common in men in different studies [17-18].

Concerning laboratory data; hemoglobin level, platelet count and serum albumin were comparable between patient groups, while serum AST, ALT, total, direct bilirubin, creatinine were significantly higher among patients with HCC.

As regards AFP, there was non-significant difference between cirrhotic patients as opposed to the control, but there was a highly significant difference between HCC versus the control and cirrhotic patients. It was significantly greater among patients with HCC.

The low specificity of AFP as a biomarker for HCC surveillance could be explained by the temporary rise in AFP levels in patients with cirrhosis reflecting an exacerbation of the hepatitis or in patients with chronic liver disease; and the flares of underlying liver disease such as $\mathrm{HBV}, \mathrm{HCV}$ or HCC advance [19].

In our work, there was measurably critical distinction between the three groups, mean + standard deviation level of HSP 70 in group I (Control) was $(91.5 \pm 13.9) \mu \mathrm{g} / \mathrm{ml}$ whereas for group II (Cirrhosis) $(116.2 \pm 18.3) \mu \mathrm{g} / \mathrm{ml}$ and group III (HCC) $(143.9 \pm 33.1) \mu \mathrm{g} / \mathrm{ml}$. 20. Gehrmann et al. [20] found that higher serum HSP70 level was found in HCC and cirrhotic patients whereas the least HSP70 levels were found in patients with unremitting hepatitis.

We found that for HSP 70 at the cutoff esteem $120 \mu \mathrm{g} / \mathrm{ml}$ has affectability $85 \%$, specificity $50 \%$ and exactness $84 \%$, whereas AFP had affectability
$87.5 \%$, specificity $75.8 \%$ and precision $89.0 \%$ but in combination with each other affectability is $91.5 \%$, specificity is $65.8 \%$ and exactness is $93.0 \%$.

HSP70 serum level in all HCC patients were through higher compared to a controls [21]. In expansion, a subgroup of patients with liver cirrhosis who in this way made HCC had higher HSP70 serum levels than patients with liver cirrhosis [22].

Gehrmann and his colleagues found that there's no distinction between HSP 70 level in patients without liver infection and sound human volunteers. Alternately, the HSP70 in patients with liver illnesses such as $\mathrm{CH}$ (incessant hepatitis), LC (liver cirrhosis), and HCC differentiated through and through from that of solid volunteers and patients without liver disease. The most elevated serum HSP70 levels in patients were found in $\mathrm{HCC}(\mathrm{N}=47,6.5 \pm 3.1 \mathrm{ng} / \mathrm{ml})$ and LC patients $(\mathrm{N}=46,6.6 \pm 5.2 \mathrm{ng} / \mathrm{ml})$. The least HSP70 levels were found in patients with $\mathrm{CH}(\mathrm{N}=50,3.9 \pm 2.4$ $\mathrm{ng} / \mathrm{ml}$ ). These values were essentially lower than those of HCC and LC patients [20].

HSP70 can moreover be utilized in separating hepatocellular adenoma and hepatocellular carcinoma. This study detailed that HSP70 immunohistochemistry is positive within the most of well-differentiated hepatocellular carcinomas cases and a subset of cases with atypical HCC. This may offer assistance within the separating normal hepatocellular adenomas from atypical tumors and hepatocellular carcinoma [23].

Karlsson et al. [24] have recognized that HSP70 as an important regulator for multiple steps of metastasis in human cancer.HSP70 drop significantly inhibits HCC cell invasion and metastasis in the two cell lines; however, the possible underlying mechanism necessitates additional exploration [25].

We concluded that HSP 70 is an accepted valid serum biomarker that can be used in combination with AFP help in the diagnosis of HCC in cirrhotic patients.

There were also some limitations, including a moderately small sample and being applied in a single center. For more evidence, we recommend that large scale prospective multicenter studies should be done to confirm the role of HSP 70 in the diagnosis of HCC. 


\section{Administrative and ethical design:}

The study protocol was accepted by the ethical committee of the faculty of medicine Zagazig University and institutional review board under the number of ZU-IRB \#4217/18-2-2018 prior to the study. All required official permissions to complete the study were obtained from the directors of the Internal Medicine and Clinical Pathology Departments. Informed consent was taken from all members in this study.

\section{Funding:None.}

\section{Conflict of interest:None.}

\section{REFERENCES}

1. Petruzziello A. Epidemiology of hepatitis B virus (HBV) and hepatitis C virus (HCV) related hepatocellular carcinoma. Open Virol J 2018; 12:26-32.

2. Bruix J, Sherman M, Llovet JM, Beaugrand M, Lencioni R,Burroughs AK.,Christensen E., et al. Clinical management of hepatocellular carcinoma. Conclusions of the Barcelona-2000 EASL conference. European Association for theStudy of the Liver. J Hepatol 2001;35:421430 .

3. El-SeragHB :Hepatocellular carcinoma. N. Engl. J. Med,2011;365, 1118-1127.

4. Malaguarnera G, Giordano M, Paladina I, Berretta $\mathrm{M}$ and Cappellani A: Serum markers of hepatocellular carcinoma. Dig Dis Sci, 2010; (55), 2744-2755.

5. Morano KA. New tricks for an old dog: the evolving world of Hsp70. Ann. N. Y. Acad. Sci. 2007; 1113: 1-14.

6. Yang X, He H,YangW, Song T, Guo C, Zheng X , Liu Q. Effects of HSP70 antisense oligonucleotide on the proliferation and apoptosis of human hepatocellular carcinoma cells. $J$ Huazhong Univ Sci Technolog Med Sci 2010 30(3):337-343

7. Lagana SM, Moreira RK, Remotti HE and Bao F. Glutamine synthetase, heat shock protein-70, and glypican-3 in intrahepatic cholangiocarcinoma and tumors metastatic to liver. Appl. Immunohistochem. Mol. Morphol. 2013 21(3): 254-257

8. Murphy ME. The HSP70 family and cancer. Carcinogenesis 2013; 34: 1181-1188.

9. Pugh RN, Murray-Lyon IM, Dawson JL, Pietroni MC, and Williams R. Transection of the oesophagus for bleeding oesophageal varices. $\mathrm{Br}$ J Surg. 1973;60:646-649.
10. ESLC Egyptian Guidelines for HCC. European Association for the Study of the Liver, European Organization for Research and Treatment of Cancer Journal of Hepatology J 2012; 56: 908943.

11. Velazquez, R.E. Rodriguez, M. and Navascues, C.A. Analysis of risk factors for hepatocellular carcinoma in patients with liver cirrhosis. Hepatology 2003; 37: 13-7.

12. Globoscan. Cancer Incidence and Mortality Worldwide: IARC Cancer Base No. 11 [Internet]. Edited by Ferlay J, Soerjomataram I, Ervik M, Dikshit R, Eser S, Mathers C, Rebelo M, Parkin DM, Forman D, Bray F: International Agency for Research on Cancer; Available from: http://globocan.iarc.fr, 2012.

13. Toyoda $\mathrm{H}$, Kumada $\mathrm{T}$ and Tada $\mathrm{T}$. Highly sensitive Lens culinaris agglutinin-reactive $\alpha$ fetoprotein: a new tool for the management of hepatocellular carcinoma. Oncology 2011; 81(Suppl 1): 61-5.

14. Ciocca DR and Calderwood SK. Heat shock proteins in cancers: diagnostic, prognostic, predictive, and treatment implications. Cell Stress Chaperones. 2005; 10(2):86-103.

15. Zakhary NI, El-Merzabani MM and El-Sawi NM. Impact of different biochemical markers in serum of patients with benign and malignant liver diseases. Journal of Advanced Research 2011; 2(1): 49-55.

16. El-Zayadi A, Abaza H and Shawky S. Prevalence and epidemiological features of hepatocellular carcinoma in Egypt- single center experience. Hepatol Res 2001; 19(2): 170-179.

17. Elbedewy TA, El-Feky S and El Sheikh MA. Serum levels of soluble Fas and soluble Fas ligand as markers for hepatocellular carcinoma in hepatitis C virus patients. International Journal of Advanced Research 2014; 2(9): 911-919.

18. Hammad LN, Abdelraouf SM and Hassanein FS. Circulating IL-6, IL-17 and vitamin D in hepatocellular carcinoma: potential biomarkers for a more favorable prognosis? J Immunotoxicol 2013; 10: 380-386.

19. Di Bisceglie AM, Sterling RK, Chung RT, Everhart JE, Dienstag JL, Bonkovesky HL, Wright EC,Everson GT. et al. Serum alphafetoprotein levels in patients with advanced hepatitis C: results from the HALT-C trial. $J$ Hepatol 2005;43:434-41.

Elhammar et al., Afro-Egypt J Infect Endem Dis 2019; 9(3):216-223

https://aeji.journals.ekb.eg/

http://mis.zu.edu.eg/ajied/home.aspx 
20. Gehrmann M, Cervello M, Montalto G, Cappello F, Gulino A. Knape C. Specht HM. Multhof G. Heat shock protein 70 serum levels differ significantly in patients with chronic hepatitis, liver cirrhosis, and hepatocellular carcinoma. Frontiersin Immunology 2014; 5: 307.

21. Multhoff $G$ and Hightower LE. Distinguishing integral and receptor-bound heat shock protein 70 (HSP70) on the cell surface by HSP70-specific antibodies. Cell Stress Chaperones, 2011, 16(3): 251-510.1007/s12192-010-0247-1

22. Kang GH, Lee BS, Lee ES, Kim SH, Lee HY, Kang DY. Prognostic significance of p53, mTOR, c-Met, IGF-1R, and HSP70 over expression after the resection of hepatocellular carcinoma. Gut Liver 2014; 8(1): 79-87.
23. Nguyen TB, Roncalli M, Di Tommaso L and Kakar S. Combined use of heat-shock protein 70 and glutamine synthetase is useful in the distinction of typical hepatocellular adenoma from atypical hepatocellular neoplasms and welldifferentiated hepatocellular carcinoma. Mod Pathol 2016; 29(3): 283-292.

24. Karlsson R, Pedersen ED, Wang $\mathrm{Z}$ and Brakebusch C. Rho GTPase function in tumor genesis. BiochimBiophysActa 2009; 1796: 91-98.

25. Hartmann S, Günther N, Biehl M, Katzer A, Kuger S, Worschech E, Sukhorukov VL, Krone G. et al. Hsp90 inhibition by NVP-AUY922 and NVP-BEP800 decreases migration and invasion of irradiated normoxic and hypoxic tumor cell lines. Cancer Lett 2013; 331: 200-210. 